\title{
Research and Analysis on the Bilingual Teaching Practice of Principles of Economics
}

\author{
Li Jin \\ School of Management, University of Jinan, \\ Jinan 250002, Shandong
}

\begin{abstract}
In recent years, the bilingual teaching has attained a rapid development in the field of education in China, and also has been expanded to all discipline categories including economy, literature, and international culture, thus promoting China's education to gradually keep pace with the world education system and generating an international development trend for the education in an all-round way. In this paper, the teaching strategies for the teaching practice of Principles of Economics are simply analyzed by taking the bilingual teaching practice examples of Principles of Economics in a college for example.
\end{abstract}

Keywords- Principles of Economics; Bilingual Teaching; Positioning; Effect; Suggestions

\section{Introduction}

Bilingual teaching means that a second language is applied to teaching in addition to the mother tongue. After China accessed to the WTO and comprehensively integrates with the world cultural forms, bilingual teaching has become an important method of the international personnel cultivation in this country. According to the explanation in the Langman Dictionary of Applied Linguistics published in the British Longman Publishing House, bilingual teaching is "the use of a second or foreign language in school for the teaching of content subjects". Based on the explanation, the American pedagogy Dr. Keith-Baker thinks that a complex phenomenon is generalized with a simple tag in bilingual teaching, and the following special properties are necessarily included in bilingual teaching: (1) it involves the learner types; (2) it involves the target language used in the classroom; (3) it has its own educational objectives, and also dominates the third model of bilingual teaching according to the different properties of different objectives: transitional bilingual teaching model, maintenance bilingual teaching model, and immersion bilingual teaching model.

\section{The realistic significance of the bilingual teaching of Principles of Economics}

\subsection{Enhancing the theory timeliness}

In the course Principles of Economics, bilingual teaching method is applied, and also the related contents reflecting the rapid, scientific development of the world economy are chosen as the dominant knowledge in the classroom, aiming to strengthen the timeliness of the teaching process. Bilingual teaching can embody the essence of the original teaching material of Principles of Economics, and also is better for the international economics personnel training model.

\subsection{Enhancing the applicability of teaching}

In bilingual teaching, the original foreign teaching materials such as Principles of Economics are adopted, aiming to highlight the high practicability of the original teaching materials. But this point is just absent in the domestic teaching materials. In the teaching material of Principles of Economics, a great number of economic cases are combined, thus helping improve the students' ability to solve the problems and more importantly apply the practical contents in the teaching material to the future actual work of students. 


\subsection{Improving the foreign language quality and scientific research of teachers and students}

Principles of Economics is taken for example: in the original teaching material, a large number of English vocabulary and grammar are involved; the competence in listening, speaking, reading and writing can be exercised and also the students' understanding of the knowledge in the teaching material can be deepened through lessons and oral English practice, if bilingual teaching is frequently integrated into the teaching process. Meanwhile, teachers must strictly implement the teaching practice activities step by step and also constantly think whether the teaching method is correct and how about its effect in the teaching activities. This is an improvement to the teachers' teaching quality and scientific research capacity in the bilingual teaching model [1].

\section{The actual condition for the bilingual teaching of Principles of Economics and the realistic condition analysis}

\subsection{The actual positioning of the bilingual teaching}

The Ministry of Education, at the beginning of the implementation of the bilingual teaching, raised a requirement as follows: the quality of the bilingual teaching courses is necessarily improved based on the contents of the higher education, so as to expand the number of bilingual teaching courses and encourage institutions of higher learning to carry out exchanges and cooperation with the international education partners to the maximum. Once the requirement was raised, the institutions of higher learning successively implemented discussion meetings about bilingual teaching courses and also proposed the highest grade standard for the undergraduate education.

From a professional point of view, Principles of Economics is a basic course in the economics program, but its teaching purpose is basically positioned to promote students to master the professional knowledge and cultivate the professional personnel. With the application of the bilingual teaching model, the personnel training direction is enriched. That is to say, the international economic personnel are trained, and foreign language becomes a new communication tool; students are expected to understand more knowledge about the foreign economy and situation in English and eliminate the invisible barriers caused by the languages in the field of the international economy.

\subsection{The condition to implement the bilingual teaching}

First, teacher is the key to implement the bilingual teaching; the educational ideas, bilingual teaching competence, and revealed personality of a teacher should be the key elements to decide whether the implementation of the bilingual teaching is successful. The bilingual teaching in China is still in its early infancy; teaching method, idea and speed are still immature, and the experience is not enough. Therefore, the prerequisite to implement the bilingual teaching lies in improving the teachers' teaching quality.

Second, the students as the taught objects also reflect the effect of the bilingual teaching. For the students studying in the economics program, the course contents are necessarily optimized using the economic terms and way of thinking in Principles of Economics; the students' different learning competence is trained according to their aptitude [2].

\section{The bilingual teaching practice case of Principles of Economics in College $\mathrm{S}$}

In the economics program of College $\mathrm{S}$, the course Principles of Economics has been introduced; the school subject construction system is built with the aid of the economics program, China-Singapore PSB cooperative education, and CIMA accounting program. 
Principles of Economics is the foundation of all kinds of economics courses. The bilingual course Principles of Economics is offered by College $\mathrm{S}$ in the third term.

\subsection{The realization of the teaching objective}

The bilingual course based on Principles of Economics is to cultivate the business management personnel adapting to the international economic development and globalization. The students are promoted to master the basic concepts of economic principles and possess professional foreign language communication competence, thus laying a good foundation for the subsequent in-depth economic course. Meanwhile, College S expects the bilingual teaching not to affect students to learn the normal major courses. The students are expected to be subtly influenced by the bilingual teaching ideas and thoughts in the normal course learning.

\subsection{The construction of the teaching model}

Substantially, the current domestic bilingual teaching mostly sources from the bilingual course concept in German-speaking region. It is in the category of the teaching methods and different from the above mentioned transitional bilingual teaching model, maintenance bilingual teaching model, and immersion bilingual teaching model. In the actual teaching process, teachers can choose a teaching way according to the course objective, the difficulty of contents, the students' English proficiency, and the teachers' foreign teaching competence. Usually, China's teachers will give top priority to the first Chinese teaching model, but the second two teaching models are adopted in College $\mathrm{S}$; in the second model, the students' English listening and speaking competence is accommodated - they are helped to adapt to the bilingual teaching in combination with the special English and also make an improve in the long process of teaching, and ultimately become capable through English and professional evaluation.

\subsection{The selection of teaching and evaluation methods}

An economic class is taken for example: a heuristic teaching method is adopted by School of Economics, College $\mathbf{S}$; group discussion is implemented in the form of class groups, and also students are required to complete an in-class course report; the students' learning initiative is stimulated by holding group contests regularly. The specific teaching mainly follows the three principles. First, the "people-oriented" teaching method is fully applied, in which students are always the centers, while teacher only plays a role in aiding students to complete the whole teaching process. Second, the bilingual teaching model is combined with a comprehensive diversified teaching way. The knowledge about the principles of economics is completely integrated into the teaching contents; the students' capability is trained on the basis of interest teaching, so as to improve the efficiency of students to participate in the course. Third, the teaching model combining theory with practice is followed. In College S, many wonderful economic activities and off-campus practice courses have been implemented to combine the social economy with the knowledge points in the theory teaching material; the teaching develops around the ideas of economics, aiming to promote the teaching and learning process to be systemic and also require students to complete a course report after class.

In the evaluation, the ways, used by different economic subjects, are relatively similar, but different in weights. Economics major courses are taken for example: the main evaluation weights are inclined to the completion of course report and group discussion - the two items account for $40 \%$ of the total scores, while the extracurricular practice occupies $20 \%$ of the total scores. In addition, mid-term test result and final test result are $10 \%$ and $30 \%$ of the total scores, respectively. In order to ensure that students keep a stable learning state and receive a good learning effect throughout the semester, the way centered 
at process monitoring is taken for the evaluation; extracurricular exercises are used for further consolidating the basic knowledge of teaching.

\subsection{Aided strategy for the bilingual classroom teaching construction}

In addition to the regular classroom teaching and the selection of evaluation ways, College $S$ hopes to establish a good bilingual environment for bilingual teaching in classroom, so as to make up for the current domestic bilingual classroom style, the poor interest of students in learning, and the weak interaction between teachers and students. Therefore, the following several strategies are specially strengthened by the school, for the goal of creating a better bilingual teaching style.

First, bilingual signs are established on campus, and this is a visual reflection to the creation of a good bilingual learning environment in College S. All places are labelled with both English and Chinese, because students are expected to rapidly get integrated into and also meet the bilingual teaching environment, and simultaneously the campus environment is more convenient for the foreign students.

Second, extracurricular activities giving top priority to English as the main tool of language are necessarily frequently implemented on campus, such as English speeches, English knowledge contests, fraternity, English reading and communication corners, English radio, and English debates. With these activities, on-campus English application style is active, thus laying a good foundation for the bilingual teaching of Principles of Economics.

Third, the cooperative education is vigorously promoted. In Principles of Economics, College $S$ directly employs foreign teachers to teach students completely in English, established a Chinese-foreign cooperation educational model based on PSB and CIMA professional construction, and exchange students with foreign colleges, so as to provide more chances for students to study abroad, broaden the professional horizons, and enrich the life experience.

Fourth, short-term overseas study tours are regularly arranged by College $S$; students are led to visit and practice in foreign enterprises, so as to learn the advanced management ideas and improve their English communication skills [3].

\section{Conclusion}

The bilingual teaching has a great effect on the development of the course Principles of Economics, but it is still in the exploration period. It is expected that a wide range of communication can be implemented with the $\mathrm{s}$ similar foreign professional schools in the future, aiming to create a good condition from both hardware and software and introduce more outstanding foreign language teaching materials such as Principles of Economic. Ultimately, a benign development is promoted based on the bilingual teaching; more practical international economic personnel are trained for the society.

\section{Acknowledgement}

This paper aided by the Fund Project, "Investigation on the Current Bilingual Teaching Situation of the Economics Courses and Study on Its Development Strategies" (No.JZC1407).

\section{References}

[1] Renwei He, Hong Yu. The Bilingual Teaching Practice and Thinking of Principles of Economics [J]. Journal of Xichang College Journal (Natural Science Edition), 2008, 22 (4): 139-142.

[2] Xin Jiang. The Practice and Thinking of the Application of the Original Foreign Language Textbooks to the Bilingual Teaching of Economics-Institute of Information Management, Heilongjiang University, Is Taken for Example [J]. Journal of Heilongjiang Education (Higher 
Education Research and Evaluation Edition), 2012, (9): 19 20.

[3] Honggang Tian. Exploration on the Bilingual Teaching Practice of Economy and
Management Specialty-Case Analysis based on the Course Principles of Economics [J]. 2011, 12 (20): 93-95. 